\title{
An Analysis of the Regulating Mechanism of the Differences between Values and Cultural Backgrounds between Countries: A Case Study of Western Countries and China
}

\author{
Di Zhou ${ }^{1}$ Hanwen $\mathrm{Li}^{2}$ \\ Macau University of Science and Technology \\ Macau 999078, China
}

\begin{abstract}
As the global political, economic, cultural, military and other fields closely and constantly strengthen, a development trend of international situation has formed. Although the main part is harmonious, it cannot be denied that there are "friction" and "contradictory" between one country and another. This situation resulted from different value orientation and cultural background. Therefore, this paper will explore the reasons for the differences of value orientation and cultural background between China and the western countries (Western countries represented by developed capitalist countries in the West), and dig the convergence between value orientation and culture by using the relevant measures.
\end{abstract}

Keywords-Western countries and China; Value orientation; Culture background; Differences; Regulative mechanism

\section{INTRODUCTION}

In recent years, with the continuous deepening of cultural exchanges between China and foreign countries, the issue of the difference between different value orientations and cultural backgrounds between countries has become more and more popular.Under the current globalization trend of international integration, a country will inevitably have various contacts with another country. However, the situation existing in reality is more complicated, and the alienation of value orientation and cultural background is likely to cause various contradictions and even conflicts. This makes the relationship between certain countries and certain countries often in disharmony. Even a state of opposition. It will also be a state of opposition. For this purpose, this requires us to study the value orientation and cultural background between different countries, and to make some theoretical analysis for achieving great harmony and great development between countries. Therefore, this article makes a relatively comprehensive discussion of the two most important values and cultural backgrounds in the world, namely the value orientation and cultural background of Western countries and China, and proposes relevant solutions.

\section{THE MAIN PERFORMANCE OF THE DIFFERENCE OF THE VALUE ORIENTATION AND THE CULTURAL BACKGROUND BETWEEN WESTERN COUNTRIES AND CHINA.}

\section{A. Overview of the country's value orientation and cultural background}

1) The connotation and essence of value orientation

Value orientation, English called value orientation, It is an important category of value philosophy, a broad concept, which refers to the basic value position, value attitude and basic value orientation of certain subjects based on their own values in dealing with various contradictions, conflicts and relationships [1]. The narrow concept, which refers to the values that people usually understand, the values are based on the certain senses of the person and the behavior of cognition, understanding, judgment or choice [2].

2) The connotation and essence of cultural background

The cultural background mainly refers to the long-term accumulation of culture as the main body of communication (human or material), and this accumulation covers the relatively stable value orientation, thinking mode and psychological structure of the communication subject [3]. In other words, the cultural background refers to the cultural differences between people, usually with different geographical tendencies, caused by different customs and habits in different regions.

3) The connotation and essence of the country's value orientation and cultural background

The state is a tool of class rule and a collection of will of all classes. The value orientation of the country mainly comes from the ruling class of the country and is the value judgment and choice of the "vested interest group", And this value judgment and choice essentially represents the will of the majority of the people in this country. In addition, the cultural background of the country is also based on the lifestyle and life process of the people living in this country. Just as the cultural background of the individual is regional, the cultural background of the country is essentially the same. 
B. Main aspects of the difference of the value orientation and the cultural background between Western countries and China

1) the way of thinking

a) Esterners and Western countries' way of thinking

Throughout the value orientation and mainstream consciousness of the Western world, which is mainly represented by developed countries, it can be seen that most Western countries emphasize the value concept of individual as the core, highlighting the importance of the individual and making some for the country. The people who contribute are worshipping, which has a strong heroism.

\section{b) Chinese and Chinese ways of thinking}

The criss-crossing Chinese cultural history is star-studded, especially with the "Confucianism" culture. It advocates a "dedication" spirit. At the same time, it also emphasizes the inherent unity of the nation itself. It determines the essence of the Chinese nation's "doing things by people" and "building a family and establishing a country", that is, the spirit of "harmony." Specifically, it is represented by "collectivism precedes individualism", "socialist core values" and outstanding values such as "being a neighbor and being a good neighbor" in diplomacy.

\section{2) Behavior aspects}

a) The way Westerners and Western countries behave

In Western countries, parents are mainly educating and cultivating their children in terms of both "independence" and "competition". For example, in the United States, a child who is only about 5 years old, after falling, his parents will not immediately help, but through language, body and other language to encourage their children to stand on their own, before the child is underage, parents Always run through a kind of "not relying on, to be independent" education awareness, and teach some "independent" skills to children, so that their children "independence" as soon as possible. When the child is an adult (18 years and older), parents will almost never take care of most of the child's life (except for some necessary living expenses), and at the same time often remind their children to have a sense of responsibility. Bear the corresponding legal obligations. Therefore, based on such "independence" and "competition" consciousness, the Westerners' performances and behaviors are mainly "positive", "direct", "tough" and "ambitious".

\section{b) Chinese and Chinese behavior}

In China, people have always advocated "thinking twice before doing", that is, considering things as much as possible to do everything. To be a man is to be gentle, to be modest and cautious, not to be reckless, to speak not too direct, to be reserved and to be restrained, but also to pay attention to "harmony and difference", "harmony and difference", "the doctrine of the mean" and other ideologies. These traditional ethical and moral concepts hardly encourage competition between people. If a person is too fond of self-expression, he may break the state of harmony and be considered to be in the limelight and not low-key.Thus, we can see at the national level that China uses these traditional ethical and moral concepts when using diplomatic means to conduct state-to-state exchanges or the development of international discourse rights, although this reflects China's friendship. With peace, sincerity and modesty, at some point, to some extent, there is still a lack of "confidence" and "toughness."

\section{Speech expression and acquisition of cognitive methods \\ 1) Speech expression}

The language transmitted through the text form pays more attention to objectivity and accuracy, but the verbal expressions of Western countries and China are different. First of all, as a language commonly used in Western countries, English is more logical, and the coherence between sentences and sentences is more compact, while the logic of Chinese is relatively loose. For example, a sentence that expresses the same meaning is expressed in English: I haven't seen you since I leave Shanghai. The expression of Chinese is: "自我离开上 海后, 我就没有见过你了。" Obviously, the English expression of the sentence is a coherent sentence, and the Chinese expression is divided into two clauses, which also use a comma to make the interval. Secondly, the meaning expression in English is not easy to cause ambiguity (except for proverbs), and some Chinese expressions are easy to make ambiguity. For example, " I want to cook noodles for you ", in English, the meaning of this sentence is straightforward,But the meaning of Chinese can be understood as "I want to cook noodles for you", Can also be understood as another vulgar and indecent.

\section{2) Gain cognitive style}

Cognitive acquisition is mainly carried out through human self-awareness and observation of things. In Western countries, people's perceptions of a thing or thing are usually obtained through analysis and solution. They are good at grasping the personality of things and finding out the differences between individuals and individuals. This has a rational meaning. Of course, in China, most people gain their own perception through intuitive and preconceived observations. This kind of cognition, to a certain extent, has a certain perceptual color, which naturally forms a kind of cognition that Chinese people often have to "seek common ground while reserving differences."

\section{THE REASONS FOR THE DIFFERENCES IN THE VALUE ORIENTATION AND CULTURAL BACKGROUND BETWEEN WESTERN COUNTRIES AND CHINA}

\section{A. Historical background factors}

As we all know, it is normal for a country to have a difference in value orientation and cultural background from other countries. However, the root cause of these differences is determined by its special historical view. Western countries, because they have experienced industrial revolution and bourgeois reform very early, their social productivity and people's material living standards have been greatly improved and improved, so that they have gradually formed "independence" and "freedom". The individuality and ideological values of "diversity", "democracy", "perseverance" and "openness". As the eastern country with the history of 
5,000 years of civilization, "China", its cultural background is full of knowledge. However, throughout the history of China's development, there are not many social stages that can bring about tremendous development of China's productive forces. Therefore, the process of industrialization is relatively slow until the establishment of New China and the subsequent national policy of "reform and opening up". The implementation of China has slowly stabilized its foothold in the world. However, the idea of "hard work" and "discipline of discipline" has always existed in Chinese society.

\section{B. Political behavioral factors}

Politics is another manifestation factor that influences the difference between the value orientation and cultural background of Western countries and China. The political system of a country determines the political path taken by this country, and its political behavior determines the interaction between this country and other countries. relationship. In the Western world, almost all Western countries have embarked on the capitalist road, and almost uniformly implemented the parliamentary system of "separation of powers." Compared with the West, the new China is taking the socialist road. Therefore, some Western countries have adopted an attitude of prejudice or hatred toward China on the socialist road from the perspective of ideology. China still adheres to its international political line of "peaceful rise" and "cooperation and win-win".

\section{Mode of thinking}

The way of thinking affects the actions of a person or a country, and different ways of thinking are subject to different sects and their ideas. For example, the Bible, a universal masterpiece that influenced the values of the entire Western world, is a Christian theological work, but it shows some "independence," "equal," "tough," and "direct." Ideas.On the contrary, in China, due to the influence of Confucianism and its ideas, people often show restrained and implicit emotional states in dealing with others. As mentioned in the Analects: The phrase "threesomes must have my teacher" is an implicit implication. It is to let people learn to be humble and learn to be sincere.

\section{USE A VARIETY OF METHODS TO FLEXIBLY HANDLE THE DIFFERENCES BETWEEN EACH OTHER AND STRIVE TO SEEK COMMON GROUND WHILE RESERVING DIFFERENCES}

\section{A. Political method}

First, politics, as a tool to serve the ruling class of the state, is a manifestation of the will of the ruling class. The polity and state of each country are not the same. This political difference is determined by the people of each country and is the path chosen by the people of each country. Therefore, respecting the political differences between each other is a prerequisite for trusting another country. For different political systems and development paths, countries can learn from each other's advantages on the basis of respect. Although Western countries have chosen to follow the path of capitalism, China has chosen to follow the socialist road with Chinese characteristics. However, as long as it is based on respect and strengthens inter-political communication and mutual trust, it can reduce or overcome differences caused by political prejudice. Secondly, when a country formulates its own policies, in addition to giving priority to its national factors, it should also proceed from the relevant provisions of the international community, especially the requirements of the UN Charter, to formulate what is applicable to its national conditions and International policy. This is conducive to the great integration between different politically inclined countries, and also provides political guarantee for the exchange of different values and cultural backgrounds between each other.

\section{B. Economic methods}

The economy is an important indicator of the level of productivity development in a country. Under the current trend of global economicization, regional integration and even the community of human destiny, this not only reflects the most direct economic exchanges between a country and another country, but also between countries, such as politics, culture, and military. Collaboration is brought about by other aspects. For this reason, even if some Western countries have political prejudice against China, economic interdependence will make this prejudice relatively narrow, because the economy is a force that cannot be underestimated in every country. Therefore, it is the easiest and most effective to reconcile the differences between Chinese and Western values and cultural backgrounds by expanding economic exchanges.

\section{Cultural methods}

Culture is a kind of soft power, an invisible soft power, and the most direct manifestation of the excellent quality of a country. The famous American political scientist Joseph Nye said in his book "Soft Power": "The source of soft power mainly comes from the attraction of culture and ideology, and soft power is a cooperative power."[4]. Obviously, the attraction and inclusiveness of culture is a fully affirmed aspect of Joseph Nye. Every country has its own excellent culture, the West has its own universal values, and China has its own cultural concept that is full of millennium. For example, the Bible is still respected by Westerners. Its core idea is "fraternity", and Chinese Confucianism also has this view. It can be seen that in terms of culture, Western countries and China can fully use this commonality between cultures to deal with each other's cultural differences.

\section{Legal methods}

As a routine means of maintaining the ruling class's governance of the state, the law is to serve politics. It is a specific norm and norm that constrains people's behavior. Here, it is important to point out that countries should strengthen the study of the legislative spirit of other countries, even seek cooperation, and at the same time deal with various objections between countries in accordance with the legal norms of international conventions or the provisions of international law. In the general theory of the ownership of private law theory, Kant divided the possession into "perceptual possession" and "rational possession". The real possession is rational possession, and it can also be called legal possession [5]. Kant's point of view shows that possession is not only the ownership of an object or event, but the legal ownership of the object or event. 
Therefore, it is also reasonable to apply Kant's legal thinking to resolve conflicts or conflicts between countries. When there is a variety of discord, contradiction or conflict between one country and another country, a country should not impose its will on other countries only by its emotional or ideological "ideas".

\section{CONCLUSION}

It is normal that there is a difference between the value orientation and the cultural background between the state and the country. People who have grown up in different cultural backgrounds and national beliefs should also have this difference. There are differences between this cultural difference and value orientation. Everyone needs to respect each other and learn from each other's strengths. As Ashley Montagu pointed out the importance of learning about human society: "Undoubtedly, we are born with the potential of genes to give to all kinds of behaviors, but the way these potentials become practical. It depends on the training we receive, depending on the study."[6]. Only in this way, the formation of you and me, I have your community of destiny, and our human society will not be forgotten by the times.

\section{ACKNOWLEDGMENT}

About the author:

Di Zhou, from Chong Qing of China, lecturer, Ph.D. in Inte rnational Relations, Macau University of Science and Technolo gy, research direction: Sino-foreign cultural exchanges.

Hanwen Li, from Xinyang, Henan, lecturer, Ph.D. in Intern ational Relation, Macau University of Science and Technology, research direction: Sino-foreign cultural exchanges.

\section{REFERENCES}

[1] Jiang Yan. The Value Orientation of Compulsory English Textbooks in Compulsory One $[\mathrm{J}]$. Reading and Writing (teaching and research edition), 2014(21): 14. (In Chinese)

[2] Sohu.com in the development of the team, can not be underestimated per sonal value [EB/OL].http://www.sohu.com/a/155186747_114819.html, 2017-07-07. (In Chinese)

[3] Shen Guofang. Strategies for Children's Conflict Resolution in Different Cultural Backgrounds [J]. Primary Science: Teachers, 2012(03): 137. (In Chinese)

[4] Zhang Xiaoming. An Analysis of Joseph Nye's Thought of "Soft Power" [J]. American Studies, 2005(01): 22-24. (In Chinese)

[5] Gu Chunde, Shi Wei. History of Western Legal Thoughts [M]. Renmin University of China Press, 2000.: 161-162. (In Chinese)

[6] Stavli Arnos. Dong Shuhui, Wang Wei, etc. Global History [M]. Beijing: Peking University Press, 2005:44. (In Chinese) 